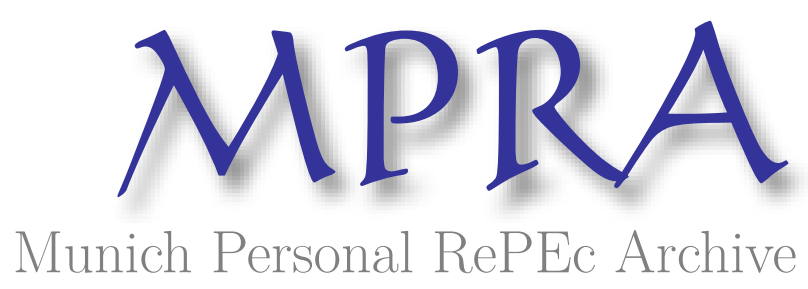

\title{
Efficacy of US Immigration Policies: What Do Available Evidence Suggest?
}

John, Raju

Baselius College Kottayam

2021

Online at https://mpra.ub.uni-muenchen.de/105684/

MPRA Paper No. 105684, posted 27 Jan 2022 03:00 UTC 


\title{
EFFICACY OF US IMMIGRATION POLICIES: WHAT DO AVAILABLE EVIDENCE SUGGEST?
}

\author{
Raju John
}

(Assistant Professor, Baselius College Kottayam, Kerala, India, rajujohn7407@gmail.com)

\begin{abstract}
This paper tries to gather available evidences pertaining to the potential effects of changes in immigration policies of United States of America (USA), the top global emigrant destination. USA government seems to go ahead with restrictions on emigration to USA. In this context, this paper attempts to examine the efficacy of such curbs using available historical and empirical evidence. It is important to gather evidence pertaining to potential impact of such curbs as they are likely to depress global emigrant flows considerably. This is likely to induce negative shocks on nations who send large number of emigrants (for ex: India). The paper is expected to provide some information regarding the historical/empirical evidence pertinent to actual association between immigration policies and immigration so that stakeholder community of emigration systems of these nations can be more realistic in their approach towards immigration curbs in USA and other major destinations.
\end{abstract}

Key Words - Migration, Emigration, Immigration, Policies, USA, DEMIG data.

JEL Classification - F22, K37, O15, R23.

\section{Introduction}

According to World Bank (2016) United States of America (USA) is the top emigrant destination in the world. Needless to say, any restriction on emigration to USA is likely to have significant bearing on global emigration flows. The trump administration tried to impose several curbs on immigration. The stand of present government is different from him. In this context, this paper attempts to examine the efficacy of US immigration policies using available historical and empirical evidence. The paper is expected to provide some information regarding the historical/empirical evidence pertinent to actual association between immigration policies and immigration 


\section{Association between policies and immigration to USA}

Data Sources - The DEMIG data base

International Migration Institute, University of Oxford had prepared a data base on DEterminants of MIGration (DEMIG). DEMIG data base consist of three data sources 1) DEMIG policy data which contain information about migration policy changes enacted by 45 nations. 2) DEMIG total data on immigration, emigration and net migration flows for more than 150 nations 3) DEMIG C2C (country-to-country) database contains bilateral migration flow data for 34 reporting nations (Demig 2015a).

The author has tried to understand the history of migration - policy nexus in USA using information from DEMIG policy data and DEMIG total data. Decadal changes in migration inflows to USA during 1875-2015 were computed first from DEMIG total data. The general nature of immigration policies during each of these decades were understood from DEMIG policy data. These two information were combined to have an idea about the history of migration (immigration) - policy nexus in USA.

Before going into findings, it is important to be aware about the limitations of the study. As said in review of literature, policy is only one among the many factors that affect immigration. Filtering of migration impact from a myriad of immigration determinants is possible only by a regression analysis. But author do not have the knowledge/expertise regarding all the determinants of migration to USA and therefore do not wish to do such an analysis. Also DEMIG data is available only up to 2015. Apart from these limitations, this study also suffers from some of methodological and conceptual difficulties discussed in review of literature. The nature of analysis is macro (aggregative) in character and micro dynamics of the policy - migration nexus are not analyzed. Still the author think that an analysis of DEMIG policy data and DEMIG total data offer some useful insights on the history of migration - policy nexus in USA that are relevant in the changing migration policy scenario in USA.

The history of migration - policy nexus in USA is represented in Table 1 which shows the decadal increase in immigration to USA and the general nature of immigration policies during each of these decades. Decadal changes in 
immigration were computed as the percentage increase in total immigration in a particular decade in comparison with the total immigration in previous decade. General nature of immigration policies in each decade were approximated by finding the percentage of immigration policies that were restrictive during each decade. (DEMIG data have information regarding the restrictiveness of immigration policies during the period of study).

Table 1: Migration - Policy Nexus in USA

\begin{tabular}{|c|c|c|}
\hline Decade & $\begin{array}{c}\text { \% Increase } \\
\text { in } \\
\text { Immigration }\end{array}$ & $\begin{array}{c}\text { Restrictive } \\
\text { Immigration } \\
\text { Polices (\%) }\end{array}$ \\
\hline $1875-1885$ & -9.22 & 100 \\
\hline $1885-1895$ & 16.40 & 75 \\
\hline $1895-1905$ & 2.14 & 100 \\
\hline $1905-1915$ & 118.67 & 50 \\
\hline $1915-1925$ & -61.00 & 56 \\
\hline $1925-1935$ & -50.65 & 100 \\
\hline $1935-1945$ & -75.56 & 0 \\
\hline $1945-1955$ & 268.07 & 50 \\
\hline $1955-1965$ & 60.91 & 50 \\
\hline $1965-1975$ & 31.80 & 0 \\
\hline $1975-1985$ & 36.51 & 37.50 \\
\hline $1985-1995$ & 88.16 & 40 \\
\hline $1995-2005$ & -12.48 & 60 \\
\hline $2005-2015$ & 28.72 & 62.50 \\
\hline
\end{tabular}

Source: Computed by author from DEMIG database

From Table 1 we can see that during 1875-1885 all immigration policies (hereafter will be referred simply 'policies') were restrictive and during this period, immigration to United States of America (hereafter will be referred simply 'immigration') declined by $9.22 \%$. During $1885-1895,75 \%$ of policies were restrictive but immigration increased by $16.4 \%$. All policies in the next decade were restrictive but immigration increased by $2.14 \%$. The period from 1905-1915 had half the policies restrictive and remaining non restrictive but immigration increased by $118.67 \%$. The policy scenario in succeeding decade (1915-25) was similar $-56 \%$ being restrictive but immigration declined by $61 \%$. In the next decade (1925-35) all policies were restrictive and immigration declined by 
$50.65 \%$. But in the succeeding decade (1935-45), none of the policies were restrictive yet immigration declined by $75.56 \%$. In the next two decades, half of the policies were restrictive but immigration increased by $268 \%$ during first (194555) decade and 60.91\% during the second (1955-65). During 1965-75, there were no restrictive policies yet immigration increased by $31.8 \%$. In the next two decades, majority of the policies were not restrictive and immigration increased by $36.51 \%$ during 1975-85 and 88.16\% during 1985-95. During 1995-2005, 60\% of policies were restrictive and immigration declined by $12.48 \%$. But in the next decade (2005-15), 62.5\% of policies were restrictive but immigration increased by $28.72 \%$.

Author tried to depict 14 decades ofUSA's immigration - policy nexus in Table 1. The following patterns can be identified from Table 1/previous paragraph.

1. Out of these 14 decades, all policies/ majority of policies were restrictive in 7 decades. During these 7 decades, immigration declined in 4 decades and increased in 3 decades.

2. In 14 decades under our consideration, all policies/ majority of policies were non restrictive in 4 decades. During these 4 decades, immigration increased in 3 decades and declined in 1 decade.

3. In the remaining 3 decades, half of the policies were restrictive and remaining non restrictive. In all these 3 decades, immigration increased.

From these patterns, some generalizations can be made on the history of migration - policy nexus in USA. The historical pattern of association between immigration and polices suggests the following;

1. There is lack of empirical evidence to conclude that restrictive immigration policies will always lead to a decline in immigration to USA. In 7 decades of restrictive policies, immigration declined only for 4 decades. In the remaining 3 decades, immigration increased. If we follow the majority rule, 
then we may conclude that restrictive policies in USA reduce immigration to USA, as that was the case in majority ( 4 out of 7 ) of decades. But at the same time, one cannot ignore the increase in immigration in 3 out of 7 decades of restrictive policies. Thus immigration to USA increased in an equally significant period were restrictive immigration policies prevailed. Thus there is lack of historical evidence that support the existence of a clear association between restrictive immigration policies and decline in immigration in USA.

2. On the other hand, there exists empirical evidence that suggests that non restrictive immigration policies are generally associated with increase in immigration to USA. Immigration increased in 3 out of 4 decades of non restrictive immigration policies. Thus there is a more clear association between non restrictive immigration policies and increase in immigration to USA.

\section{Conclusion}

This study was an attempt to examine the efficacy of recent changes in policies pertaining to immigration to United States of America using available empirical evidence. Immigration to USA increased even the era of restrictive immigration policies. So history seems to offer some hope to prospective emigrants to USA even if policies remain restrictive. 


\section{Bibliography}

Beine, M., Docquier,F and Özden, Çaglar. (2011). "Diasporas." Journal of Development Economics 95(1):30-41.

Bhagwati, J. (2003). "Borders beyond control." Foreign Affairs January/February:98-104.

Boswell, Christina. (2007). "Theorizing Migration Policy: Is There a Third Way?" International Migration Review41(1):75-100.

Brachet, Julien (2005). "Migrants, Transporteurs et Agents d'Etat : Rencontre sur l'Axe Agadez-Sebha." Autrepart 36(4):43-62.

Brochmann, Grete, and Tomas Hammar (Eds.). (1999). Mechanisms of Immigration Control. Oxford/New York:

Broeders, D., and G. Engbersen. (2007). "The fight against illegal migration Identification policies and immigrants' counterstrategies." American Behavioral Scientist 50(12):1592-609.

Castles, Stephen. (2004). "Why migration policies fail." Ethnic and Racial Studies 27(2):205-27.

Castles, Stephen, and Mark. J. Miller. (2009). The Age of Migration. Houndmills, Basingstoke, Hampshire and London: MacMillan Pres ltd.

Cornelius, W. A. (2001), "Death at the Border: Efficacy and Unintended Consequences of US Immigration Control Policy", Population and Development Review 27, no. 4: 661-685.

Cornelius, Wayne A., Takeyuki Tsuda, Philip L. Martin, and James Frank Hollifield (Eds.). (2004). Controlling immigration : a global perspective. Stanford, Calif.: Stanford University Press.

Czaika, Mathias and Haas, Hein de (2011). The effectiveness of immigration policies - A conceptual review of empirical evidence, Working PapersPaper 33, April 2011, DEMIG project paper 3, International Migration institute, Oxford, University of Oxford. 
Czaika, Mathias and Haas, Hein de (2014).The Effect of Visa Policies on International MigrationDynamics, Working Papers Paper 89, April 2014, DEMIG project paper 18, International Migration institute, Oxford, University of Oxford.

Czaika, Mathias (2015). Evaluating migration policy effectiveness, IMI, University of Oxford, Athens, 8 July 2015.

Czaika, M. and de Haas, H., (2013). The Effectiveness of Immigration Policies. Population and Development Review, 39(3), 487-508.

Czaika, M. and de Haas, H., (2014). The Effect of Visa Policies on International Migration Dynamics.International Migration Institute Working Paper 89. Oxford: IMI.

Czaika, M. and Hobolth, M., (2014). Deflection into Irregularity? The (Un)Intended Effects of Restrictive Asylum and Visa Policies. International Migration Institute Working Paper 84. Oxford: IMI.

Czaika, M. and Parsons, C., (2015). The Gravity of High-Skilled Migration Policies. International Migration Institute Working Paper 110. Oxford: IMI.

de Haas, Hein (2010). "The internal dynamics of migration processes: A theoretical inquiry." Journal of Ethnic and Migration Studies 36(10):1587-617.

de Haas, Hein. (2011). The Determinants of International Migration, DEMIG Working Paper 2. Oxford: University of Oxford: International Migration Institute.

De Haas, Hein and Vezzoli, Simona (2011). Leaving matters - The nature, evolution and effects ofemigration policies, Working Papers Paper 34, April 2011, DEMIG project paper 4, International Migration institute, Oxford, University of Oxford.

DEMIG (2015a)Demig Data, Oxford: International Migration Institute, University of Oxford.https://www.imi.ox.ac.uk/data/demig-data Accessed on 6 February 2017

DEMIG (2015b) Demig Policy, version 1.3, Online Edition. Oxford: International Migration Institute, University of Oxford. www.migrationdeterminants.eu, accessed on $6^{\text {th }}$ February 2017. 
DEMIG (2015c) Demig Total, version 1.5. Oxford: International Migration Institute, University of Oxford. www.migrationdeterminants.eu, accessed on $6^{\text {th }}$ February 2017.

Desipio, L. (2002), "Sending money home < for now: remittances and immigrant adaptation in the UnitedStates", Sending Money Home: Hispanic Remittances and Community Development: 157-87.

Dorantes, Catalina - Amuedo and Pozo, Susan (2006). Migration, Remittances, and Male and Female Employment Patterns, American Economic Review, vol. 96, no. 2, May 2006, pp. 222-226

Espenshade, T. (1994), "Does the threat of border apprehension deter undocumented us immigration?",Population and Development Review 20, no. 4: $871-892$

Federal Register (2017a). Protecting the Nation from Foreign Terrorist Entry Into the United States, Executive Order 13769 of January 27, 2017Federal Register, United States of America, Vol. 82, No. 20, Wednesday, February 1, 2017, Presidential Documents, Title 3, pp 8977 - 8982.

Federal Register (2017b). Protecting the Nation from Foreign Terrorist Entry Into the United States, Executive Order 13780 of March 6, 2017Federal Register, United States of America, Vol. 82, No. 45, Thrusday, March 9, 2017, Presidential Documents, Title 3, pp $13209-13219$.

Hatton, T. J. (2004). "Seeking Asylum in Europe." Economic Policy 19:5-62.

Hatton, T. J. (2005). "Explaining trends in UK immigration." Journal of Population Economics 18(4):719-40.

Hatton, T. J. (2009). "The Rise and Fall of Asylum: What Happened and Why?" Economic Journal 119(535):F183-F213.

Hatton, Timothy J., and Jeffrey G. Williamson. (1998). The Age of Mass Migration: Causes and Economic Impact. New York: Oxford University Press. 
Infantino, Federica (2010). "La frontière au guichet. Politiques et pratiques des visas Schengen aux Consulat et à l'Ambassade d'Italie au Maroc." Champ pénal / Penal field, nouvelle revue internationale de criminologieVII(24 septembre 2010).

IOM (2001), "Binational Study: the State of Migration Flows between Costa Rica and Nicaragua",International Organization for Migration, 2001

Karemera, D., V. I. Oguledo, and B. Davis. (2000). "A Gravity Model Analysis of International Migration to North America." Applied Economics 32:1745-55.

Kossoudji, S. A. (1992), "Playing Cat and Mouse at the US-Mexican Border", Demography 29, no. 2: 159-180

Mahía, Ramón, Thielemann, Eiko and de Arce, Rafael (2010). Immigration Policy and its Impact: A comparative Study with A Focus on Spain, CIEES \& LSE, London, The London School of Economics and Political Science, January, 2010

Massey, Douglas S. (1990). "Social Structure, Household Strategies, and the Cumulative Causation of Migration." Population Index 56:3-26.

Massey, D. S. and Espinosa, K. E. (1997), "What's Driving Mexico-US Migration? A Theoretical, Empirical,and Policy Analysis", The American Journal of Sociology 102, no. 4: 939-999.

Massey, Douglas S., Joaquín Arango, Graeme Hugo, Ali Kouaouci, Adela Pellegrino, and J. Edward Taylor. (1998). Worlds in motion: Understanding international migration at the end of the millennium. Oxford: Clarendon Press.

Massey, D., Durand, J. and Malone, N. (2003), Beyond smoke and mirrors: Mexican immigration in an era ofeconomic integration: Russell Sage Foundation Publications.

Niessen, Jan, and Thomas Huddleston. (2009). Legal frameworks for the integration of third-country nationals. Leiden ; Boston: Martinus Nijhoff Publishers.

Orrenius, P. (2004), "The effect of US border enforcement on the crossing behavior of Mexican migrants",Crossing the Border: Research from the Mexican Migration Project: 281-298. 
Ortega, Francesc, and Giovanni Peri. (2009). The Causes and Effects of International Migrations: Evidence from OECD Countries 1980-2005: NBER Working Paper No. 14833.

Ortega, Francesc, and Giovanni Peri. (2013). "The effect of income and immigration policies on international migration." Migration Studies 1(1):47-74.

Reyes, B. (2004), "US immigration policy and the duration of undocumented trips", Crossing the Border:Research from the Mexican Migration Project: 299321.

Ruhs, Martin. (2011). Openness, Skills and Rights: An Empirical Analysis of Labour Immigration Programmes in 46 High and Middle-income Countries. COMPAS Working Paper WP-11-88. Oxford: COMPAS, University of Oxford.

Taylor, J. E. (1992), "Remittances and inequality reconsidered: Direct, indirect, and intertemporal effects", Journal of Policy Modeling 14, no. 2: 187-208.

Taylor,J. Edward and Filipski, Mateusz (2011). The Impact of Migration Policies on Rural Household Welfare in Mexico and Nicaragua, OECD Development Centre Working Paper No.298 DEV/DOC(2011)5 May 2011

Thielemann, E (2004). Does Policy Matter? On Governments' Attempts to Control Unwanted Migration: CCIS Working Paper No. 112, University of California, San Diego.

Vogler, M., and R. Rotte. (2000). "The effects of development on migration: Theoretical issues and new empirical evidence." Journal of Population Economics 13(3):485-508.

World Bank (2016). Migration andRemittancesFactbook 2016, 3rd Edition, Washington, International Bank for Reconstruction and Development / The World Bank.https://openknowledge.worldbank.org/bitstream/handle/10986/23743/978146 4803192.pdf?sequence=3\&isAllowed $=y \quad$ Accessed on 23 April 2017. 